\title{
Annual General Meeting
}

The President, the Marquess of Willingdon, will take the chair at the 66th Annual General Meeting of the Society in the Meeting Room of the Zoological Society of London, Regent's Park, NWI, on Wednesday June Ioth, r970, at 6 p.m. After the meeting Nigel Sitwell, Editor of Animals, will speak on his recent visit to Indonesia, and Lady Lathbury has kindly agreed to show some of her films of African wildlife. A wine and cheese supper will be served at 7.45 p.m.

\section{Agenda}

I. Minutes of the Annual General Meeting, I969.

2. Presentation and Discussion of the Annual Report (overleaf).

3. Presentation and Discussion of the Accounts and Auditors' Report (see overleaf).

4. Election of Officers (see below).

5. Election of Council Members (see below).

6. Vote of thanks to the Zoological Society of London.

\section{Officers and Council}

Council recommend that the following Members should be elected as Officers of the Society for 1969-70:

President: The Marquess of Willingdon

Chairman of Council: Peter Scott, CBE, DSC

Vice-Chairman of Council: Sir Terence Morrison-Scott, DSC, DSc Honorary Treasurer: Ian D. Malcolmson, TD

Honorary Secretary: Richard Fitter

The following members of Council retire at the Annual General Meeting and are not eligible for appointment for one year:

F. Fraser Darling, DSc, FRSE

Marcus Kimball, MP

Major W. N. Scott

Council has appointed the following to fill these vacancies, and their names are submitted for confirmation:

Christopher Cadbury

Dr Malcolm Coe

W. A. R. Collins 